\title{
ANALISIS REFLEKTANSI SPEKTRAL LAMUN MENGGUNAKAN SPEKTROMETER DI PULAU TUNDA SERANG, BANTEN
}

\section{SEAGRASS SPECTRAL REFLECTANCE ANALYSIS USING SPECTROMETER IN TUNDA ISLAND SERANG, BANTEN}

\author{
Nunung Noer Aziizah', Vincentius P Siregar², Syamsul Bahri Agus ${ }^{2}$ \\ ${ }^{1}$ Program Studi Teknologi Kelautan, Sekolah Pascasarjana \\ ${ }^{2}$ Departemen Ilmu dan Teknologi Kelautan \\ Fakultas Perikanan dan Ilmu Kelautan, Institut Pertanian Bogor \\ Korespondensi : nunungnoeraziizah@yahoo.com
}

\begin{abstract}
Research of object spectral reflectance has develop and giving data or information about spectral pattern. Objects that are used in this study was seagrass, which plant with ability to adapt with high salinity water. The problem arrise was how extent object spectral that observed was able to giving an overview of different characteristics of the object in the field. The experiment was conducted in seagrass Tunda Island Serang District in August 2014 and resumed in March 2015. The aim of this research was to determine seagrases spectral reflectance curve, spectral characteristics, and identifier wavelength which gave different characteristics from each type of seagrass. In situ reflectance measurements by using USB4000 spectrometer which generate intensity value and analysis using reflectance algorithms to generate the curve. Reflectance curve has two peaks at wavelengths $500-650 \mathrm{~nm}$ and $700-750 \mathrm{~nm}$ with a highest value was $22 \%$ ) in the first peak and $14 \%$ in the second peak. The result from statistic analysis showed the reflectance values of five species of seagrass in Tunda Island is significantly different. Based on the reflectance values of the five species of seagrass and Tukey test has been done, it is known wavelength identifier for five species of seagrasses have significant differences that wavelenght of green, yellow, red edge, and NIR-2.
\end{abstract}

Keywords: reflectance, seagrass, spectrometers, Tunda Island

\begin{abstract}
ABSTRAK
Analisis reflektansi spektral suatu objek mulai banyak berkembang dan memberikan data atau informasi tentang pola spektral. Objek dalam penelitian ini adalah lamun, yang merupakan tanaman memiliki kemampuan untuk beradaptasi hidup di perairan dengan salinitas tinggi. Permasalahan yang muncul adalah sejauh mana pola spektral objek mampu memberikan gambaran yang sesuai dengan karakteristik objek di lapangan. Penelitian dilaksanakan di ekosistem lamun Pulau Tunda Kabupaten Serang pada bulan Agustus 2014 dan dilanjutkan bulan Maret 2015. Tujuan dari penelitian ini adalah mendapatkan kurva reflektansi spektral lamun, karakteristik spektral, dan identifikasi panjang gelombang yang memberikan karakteristik berbeda dari setiap jenis lamun. Pengukuran reflektansi insitu menggunakan spektrometer USB4000 menghasilkan nilai intensitas dan dianalisis menggunakan algoritma reflektansi untuk menghasilkan kurva. Kurva reflektansi memiliki dua puncak pada panjang gelombang 500-650 nm dan 700-750 nm dengan nilai tertinggi adalah $22 \%$ di puncak pertama dan $14 \%$ di puncak kedua. Hasil dari analisis statistik menunjukkan nilai reflektansi dari lima spesies lamun di Pulau Tunda berbeda signifikan. Berdasarkan nilai reflektansi dari lima jenis lamun dan uji Tukey yang telah dilakukan, dapat diketahui panjang gelombang penciri karena lima jenis lamun memiliki perbedaan signifikan yaitu pada panjang gelombang hijau, kuning, merah tepi, dan NIR-2.
\end{abstract}

Kata kunci: lamun, Pulau Tunda, reflektansi, spektrometer 


\section{PENDAHULUAN}

Kajian mengenai subtrat dasar perairan telah berkembang pada pengukuran variasi spektral (Holden \& LeDrew 2001). Respons spektral yang ditangkap oleh sensor spektrometer salah satunya adalah reflektansi. Reflektansi merupakan besarnya energi gelombang elektromagnetik yang dipantulkan oleh suatu benda. Pengukuran spektral suatu objek dengan teknologi penginderaan jauh dilakukan dengan melihat segala bentuk pantulan yang diolah menjadi informasi, dan direkam oleh alat yang dinamakan sensor (Lillesand et al. 2004).

Sifat gelombang yang dipantulkan, diserap, diteruskan maupun dipancarkan sangat bervariasi tergantung pada karakteristiknya di permukaan bumi (Mobley 1994). Variasi sifat gelombang yang berbeda menjelaskan setiap objek di bumi mempunyai reaksi spektral (spectral respond) yang berbeda. Sistem penginderaan jauh satelit yang mempunyai kepekaan terhadap spektral (spectral sensitivity) memanfaatkan respon spektral sebagai dasar terbentuknya data penginderaan jauh (Mobley 1994; Green et al. 2000).

Penelitian yang mengukur respon spektral lamun secara insitu di Indonesia masih sangat minim, sehingga perlu dilakukan berbagai kajian dalam hal pengukuran spektral lamun. Perbedaan respons spektral jenis lamun dapat disebabkan oleh beberapa faktor seperti karakteristik jenis yang berbeda baik secara morfologi, maupun kandungan pigmentasi di dalamnya sebagai penciri masing-masing jenis.

Ekosistem lamun memiliki peran penting dalam ekologi kawasan pesisir, karena menjadi habitat berbagai biota laut termasuk menjadi tempat mencari makan (feeding ground) (Bortone 2000). Peran lain dari ekosistem lamun adalah sebagai pendaur zat hara, menstabilkan dan menahan sedimen yang dibawa oleh arus dan gelombang (Kiswara \& Ulumuddin 2009). Berbagai fungsi yang dimiliki lamun menjadikan latar belakang untuk melakukan kajian yang berkaitan dengan sebaran lamun secara spasial.

Pengukuran spektral lamun dilakukan di Pulau Tunda yang berada di wilayah perairan Serang-Banten. Lokasi penelitian merupakan salah satu dari 17 pulau yang berada di Kabupaten Serang, Banten. Secara geografis Pulau Tunda berada pada $5^{\circ} 48^{\prime}$ 43" LS dan $106^{\circ}$ 16' 47' BT. Potensi sumberdaya hayati pesisir Pulau Tunda sangat tinggi seperti mangrove, terumbu karang, ikan karang, dan lamun. Dinas Kelautan dan Perikanan Kabupaten Serang tahun 2012 melakukan inventarisasi berbagai ekosistem di perairan Pulau Tunda salah satunya adalah lamun. Lima jenis lamun di temukan di Pulau Tunda, yaitu Cymodocea rotundata, Cymodocea serrulata, Enhalus acoroides, Halophila ovalis, dan Thalassia hemprichii.

Penelitian dilakukan secara insitu untuk mengetahui reflektansi lamun yang ditemukan di Pulau Tunda. Ruang lingkup penelitian dijelaskan pada Gambar 1 . Pengamatan dan pengukuran lapangan dilakukan untuk mengetahui jenis dan kerapatan lamun secara in situ. Respon spektral lamun diukur menggunakan spektrometer untuk memperoleh nilai reflektansi sebagai respon spektral. Nilai reflektansi lamun Pulau Tunda dianalisis secara statistik menggunakan ANOVA dan cluster analysis untuk mengetahui karakteristik spektral masing-maisng jenis dan panjang gelombang yang menjadi penciri dari perbedaan karakteristik tersebut.

Spektrometer digunakan untuk membedakan jenis lamun berdasarkan respons spektralnya. Data insitu menjadi data acuan penyesuaian respon spektral dengan jenis lamun. Analisis reflektansi dilakukan untuk melihat perbedaan spektral masing-masing jenis lamun. Perbedaan respons tersebut yang dapat digunakan untuk mengklasifikasi lamun menggunakan citra satelit pada penelitian lanjutan.

Tujuan dari penelitian ini adalah untuk menganalisis pola reflektansi spektral lamun dan menentukan panjang gelombang penciri sebagai pembeda karakteristik spektral. 


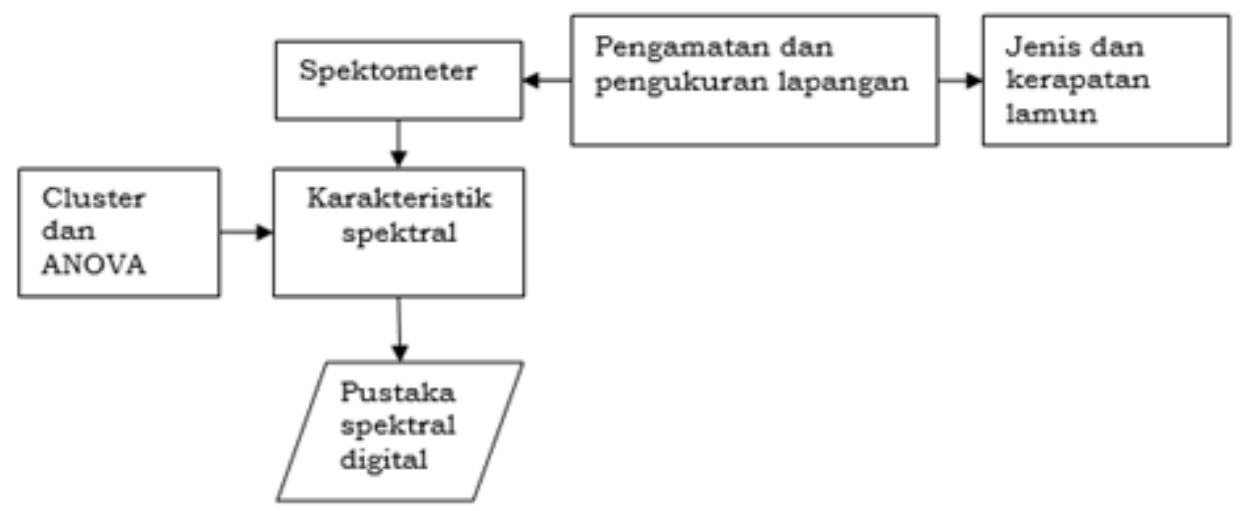

Gambar 1. Skema pelaksanaan penelitian

\section{METODE PENELITIAN}

Pengukuran respons spektral dilakukan di ekosistem lamun Pulau Tunda, Provinsi Banten (Gambar 2). Diawali dengan tahapan survei lapangan, dilanjutkan dengan pengamatan dan pengukuran yang menghasilkan data spektral. Pengamatan dan pengukuran di lapangan dilakukan pada bulan Agustus 2014 dan dilanjutkan pada bulan Maret 2015.

Alat yang digunakan untuk pengambilan data lapangan terdiri dari Spektrometer USB4000 dan GPS Trimble Juno 3D. Bahan yang digunakan adalah citra worldview-2 (standar level $2 \mathrm{~A}$ 16bit) diakuisisi 25 Agustus 2013 dengan sistem proyeksi koordinat UTM zona 48S-WGS84. Karakteristik citra worldview-2 terdiri dari 8 band (saluran) multispektral (coastal, blue, green, yellow, red, red-edge, NIR1 dan NIR2) dengan resolusi spasial $1.8 \mathrm{~m}$ dan pankromatik dengan resolusi spasial $0.5 \mathrm{~m}$ (Digitalglobe 2010).

\section{Pengukuran reflektansi spektral}

Respons spektral diukur menggunakan spektrometer USB 4000 yang disambungkan dengan perangkat komputer dan software spectra suite. Tahapan dalam pengambilan data reflektansi lamun adalah: 1. Tahap persiapan alat. Kalibrasi alat ini dilakukan dengan mengukur white reference dan dark reference spectra. Kalibrasi alat ini dilakukan untuk mendapatkan nilai referensi spektrum dan sekaligus untuk menghaluskan tampilan spektrum.

2. Tahap pengambilan data. Pengambilan dilakukan pada pukul 10:00-14:00
WIB. Probe diarahkan ke lamun dengan sudut 450 dan jarak 2-5 cm. Koordinat geografik pada tiap lokasi pengamatan direkam melalui GPS. Perekaman gambar dilakukan pada lamun dan sekitarnya, dan pencatatan informasi pendukung dilakukan secara bersamaan dengan pengukuran spektral. Informasi yang tercatat adalah: jenis lamun, jenis substrat, ukuran, bentuk, kedalaman air dan informasi yang bersangkutan lainnya di lokasi.

\section{Analisis reflektansi spektral lamun}

Hasil pengukuran di lapangan berupa nilai intensitas yang disimpan dalam format txt dan Prospec (Ocean Optic 2009). Untuk menghitung reflektansi digunakan rumus sebagai berikut:

$$
\% \mathrm{R} \lambda=\frac{S_{\lambda}-D_{\lambda}}{R_{\lambda}-D_{\lambda}} \quad \mathrm{x} 100
$$

Keterangan:

$\mathrm{R} \lambda=$ Reflektansi $(\%)$

$S \lambda=$ Intensitas sampel (counts)

$D \lambda=$ Intensitas dark (counts)

$R \lambda=$ Intensitas reference (counts)

Persen reflektansi diolah dengan melakukan filterisasi terhadap raw data dengan cara:

1. Melakukan pemotongan panjang gelombang dari 400-900 $\mathrm{nm}$ dan smoothing data dengan metode moving average.

2. Lakukan perhitungan menggunakan persamaan untuk mendapatkan nilai reflektansi

Metode moving average (rataan bergerak) akan menghitung nilai reflektansi 
di setiap panjang gelombang dengan peratarata menggunakan dimensi $3 \times 3$, maka diperoleh sembilan data yang harus diratarata untuk mendapat sebuah nilai reflektansi pada sebuah panjang gelombang (Mathews Kurtis 2004). Data spektral yang diperoleh dari masing-masing jenis lamun dianalisis statistik untuk mengetahui karakteristik dan panjang gelombang penciri.

\section{Analisis pola reflektansi spektral}

1. Analisis Deskriptif merupakan analisis dengan melihat nilai panjang gelombang (X) dan nilai reflektansi (Y) yang terbentuk pada kurva reflektansi spektral.

2. Analisis ANOVA dilakukan untuk mengetahui apakah spektral reflektansi lima jenis lamun berbeda nyata atau tidak berbeda nyata yaitu dengan uji Anova satu arah (Mattjik \& Sumertaja 2011). Hipotesis yang diuji adalah pengaruh panjang gelombang terhadap reflektansi lamun dengan HO (tidak ada pengaruh panjang gelombang terhadap reflektansi lamun), dan $\mathrm{H} 1$ (terdapat pengaruh panjang gelombang terhadap reflektansi lamun). Jika terdapat pengaruh panjang gelombang terhadap reflek-tansi maka dilakukan uji lanjut dengan uji Tuckey pada taraf kepercayaan $(95 \%) \quad(\mathrm{P}<0.05)$ untuk mengetahui perbedaan spektral antar spesies (Supranto 2004).

3. Analisis Kelompok (Cluster Analysis) digunakan dengan tujuan untuk menentukan similaritas spektral lamun dengan ukuran kemiripan yang digunakan adalah jarak euklidean (euclidean distance).

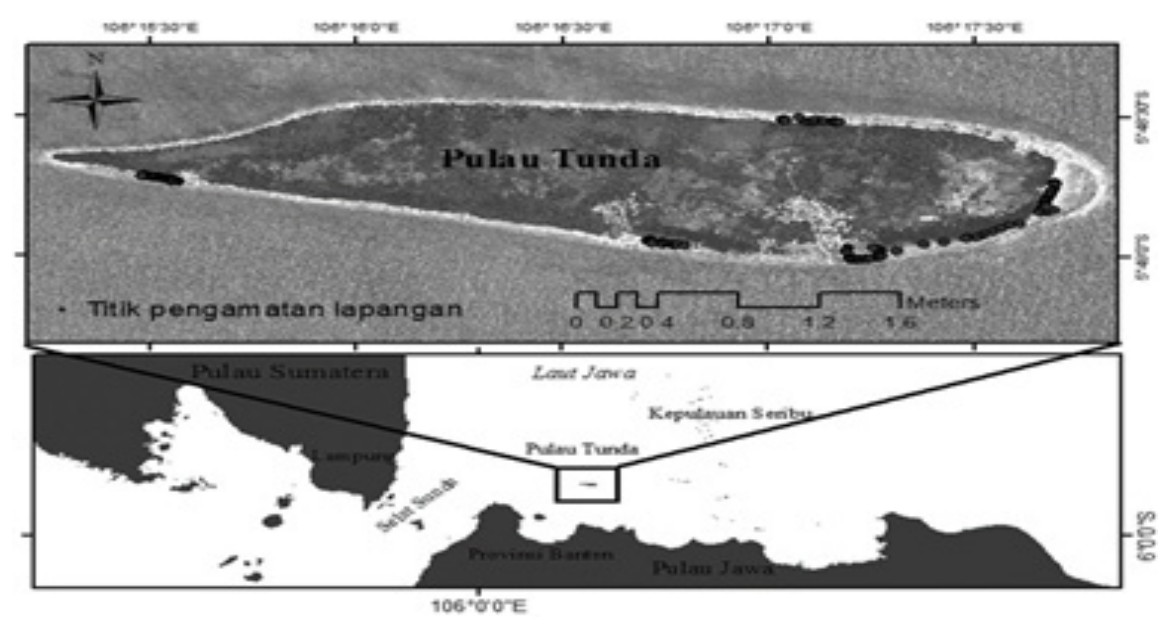

Gambar 2. Lokasi penelitian (WorldView-2 2013)

\section{HASIL DAN PEMBAHASAN}

\section{Karakteristik spektral reflektansi lamun}

Telah diperoleh lima jenis lamun yakni Cymodocea rotundata, Cymodocea serrulata, Enhalus acoroides, Thalassia hemprichii, dan Halophila ovalis. Sebagai tumbuhan, lamun membutuhkan radiasi matahari dalam bentuk gelombang elektromagnetik yang dapat direflektansikan, diserap dan ditransmisikan secara berbeda untuk setiap obyek di bumi (Lillesand et al. 2004). Perbedaan sifat optik antar spesies lamun yang utama disebabkan karena adanya variasi pigmen dan fungsi anatomi daun (struktur internal, serat, dan lain-lain) (Daruko 2007).

Tahapan analisis spektral reflektansi jenis lamun di awali dengan melakukan curvitting terhadap metadata. Kurva lima jenis lamun jika diamati secara visual memiliki pola reflektansi spektral yang sama akan tetapi memiliki nilai yang berbeda (Gambar 3). Reflektansi lamun memiliki dua peak (puncak) pada panjang gelombang 500-650 nm (band hijau) dan 700-750 nm (merah tepi) dengan nilai tertinggi (22\%) di puncak pertama dan 14\% di puncak kedua. Berdasarkan Gambar 4 dapat diketahui nilai reflektansi Cymodocea rotundata memiliki dua puncak yaitu pada panjang gelombang 500-650 nm dengan nilai $17 \%$ dan di $700-750 \mathrm{~nm}$ dengan nilai 13\%. Cymodocea serrulata memiliki dua puncak yaitu pada panjang gelombang 500-650 nm dan 700-750 nm dengan nilai masing-masing $18 \%$ dan $12 \%$. Enhalus acoroides memiliki dua puncak yaitu pada panjang gelombang 500-650 nm dengan 
nilai $21 \%$ dan di $700-750 \mathrm{~nm}$ dengan nilai 13\%. Thalassia hemprichii memiliki dua puncak yaitu pada panjang gelombang 500$650 \mathrm{~nm}$ dengan nilai $20 \%$ dan di $700-750 \mathrm{~nm}$ dengan nilai 9\%. Halophila ovalis memiliki dua puncak yaitu pada panjang gelombang 500-650 nm dengan nilai $14 \%$ dan di $700-$ $750 \mathrm{~nm}$ dengan nilai $11 \%$.

Perbandingan sebaran rata-rata reflektansi spektral lamun menunjukkan pola yang memiliki dua puncak pada panjang gelombang sinar tampak yaitu hijau-kuning (500-650 $\mathrm{nm})$ dan panjang gelombang merah (700-750 nm). Hal tersebut sesuai dengan penelitian Pu et al. (2012) dan Fyfe (2003) yang mengukur pola reflektansi spektral lamun dan menunjukkan adanya puncak di panjang gelombang 500-650 nm dan 700-800 nm. Adanya kesamaan pola reflektansi tidak menunjukkan lima jenis lamun memiliki nilai yang sama karena pada dasarnya menurut Indarto (2014) reflektansi spektral setiap objek di permukaan bumi umumnya unik (bersifat khusus atau khas yang mencirikan objek) sehingga memiliki nilai yang berbeda dengan cirinya masingmasing.

Thorhaug (2007) menjelaskan bahwa spektral reflektansi lamun juga dipengaruhi oleh kesehatan berdasarkan kondisi daunnya. Kandungan klorofil dalam daun lamun yang berwarna hijau memberikan hasil reflektansi dengan puncak tertinggi dipanjang gelombang $550 \mathrm{~nm}$ atau merupakan band hijau. Band hijau memiliki sensitivitas tinggi terhadap vegetasi sehingga dalam pengukuran reflektansi lamun puncak tertinggi berada pada interval panjang gelombang spektrometer 510-550 nm (Ocean Optics 2009). Puncak kedua berada pada rentang panjang gelombang $700-720 \mathrm{~nm}$ dan menurun pada spektrum infra merah, hal tersebut karena kolom air akan menyerap hampir semua radiasi elektromagnetik pada spektrum ini sehingga terjadi penurunan nilai reflektansi (Lillesand et al. 2004).

\section{Analisis statistik spektral reflektansi lamun}

\section{Analisis ANOVA}

Nilai reflektansi menunjukkan lima jenis lamun memiliki spektral reflektansi yang berbeda nyata dengan nilai $\mathrm{F}_{\text {hitung }}>$ dari $\mathrm{F}_{\text {tabel }}$. Kesimpulan dari pengujian menggunakan Anova adalah menolak
HO, artinya bahwa dari variabel panjang gelombang yang diuji terdapat perbedaan spektral yang signifikan antarjenis sehingga perlu dilakukan uji lanjut untuk mengetahui perbedaannya. Hasil uji Tukey dari nilai reflektansi terhadap keseluruhan panjang gelombang disajikan pada Tabel 1 .

Uji Tukey memberikan hasil analisis berupa nilai signifikansi antar spesies dimana nilai $\mathrm{p}<0.05$ menunjukkan bahwa antarspesies lamun memiliki perbedaan yang signifikan dan sebaliknya, $p>0.05$ menunjukkan bahwa antar spesies lamun tidak memiliki perbedaan yang signifikan berdasarkan nilai reflektansinya. Hasil menunjukkan tidak berbeda signifikan antara Cymodocea rotundata dengan Cymodocea serrulata, Enhalus acoroides, Thalassia hemprichii, dan Halophila ovalis. Jenis Cymodocea serrulata tidak berbeda signifikan dengan keempat jenis lain. Jenis Enhalus acoroides tidak berbeda signifikan dengan Cymodocea rotundata dan Cymodocea serrulata, sedangkan dengan Thalassia hemprichii dan Halophila ovalis terdapat perbedaan signifikan. Analisis terhadap Thalassia hemprichii menunjukkan perbedaan yang signifikan dengan Enhalus acoroides, sedangkan dengan Cymodocea serrulata, Cymodocea rotundata, dan Halophila ovalis tidak berbeda signifikan. Lamun jenis Halophila ovalis menunjukkan hasil yang tidak berbeda signifikan terhadap Cymodocea rotundata, Cymodocea serrulata, dan Thalassia hemprichii, sedangkan dengan Enhalus acoroides memiliki perbedaan yang signifikan. Uji Tukey dilakukan terhadap masing-masing rentang panjang gelombang berdasarkan jumlah saluran (band).

Berdasarkan analisis Tukey menunjukkan bahwa lamun jenis Enhalus acoroides berbeda signifikan dengan jenis Thalassia hemprichii dan Halophila ovalis atau dapat dikatakan bahwa ketiga jenis tersebut tidak memiliki kemiripan satu sama lain. Secara morfologi bentuk dan ukuran daun, ketiganya memiliki perbedaan yang signifikan. Daun Enhalus acoroides cenderung panjang hingga berukuran 1 $\mathrm{m}$, Thalassia hemprichii ukurannya lebih pendek hanya mencapai $10-15 \mathrm{~cm}$, dan daun Halophila ovalis jauh lebih kecil yaitu $1 \mathrm{~cm}$ (Azkab 2000). Daun lamun merupakan salah satu faktor yang mempengaruhi perbedaan nilai reflektansi karena sebagian energi yang dipantulkan berasal dari daun sehingga perbedaan morfologi daun sangat mempengaruhi reflektansi. 


\section{Analisis pengelompokan nilai reflektansi (Cluster analysis)}

Secara teori (Sudiana \& Diasmara 2008) vegetasi menyerap gelombang tampak (visible) biru, merah dan memantulkan gelombang hijau. Pantulan paling dominan pada tanaman adalah gelombang inframerah dekat (NIR). Sehingga diasumsikan perbedaan nilai reflektansi pada panjang gelombang NIR sebagai gelombang yang dipantulkan dan gelombang merah yang sebagian besar diserap dapat memberikan hasil yang berbeda signifikan maupun tidak berbeda signifikan atau memiliki kemiripan.

Berdasarkan nilai reflektansi dari lima jenis lamun dan uji Tukey yang telah dilakukan, dapat diketahui bahwa lima jenis lamun memiliki perbedaan signifikan pada panjang gelombang hijau, kuning, merah tepi, dan NIR-2. Prahasta (2008) menjelaskan bahwa vegetasi sensitif terhadap panjang gelombang hijau dan NIR. Panjang gelombang kuning dan merah tepi yang terdapat pada citra satelit worldview-2 memiliki spesifikasi untuk mendeteksi vegetasi dan untuk melihat prduksi klorofil dari vegetasi tersebut (Wolf 2010).

Hasil pengelompokkan dengan metode cluster analysis dijelaskan pada Tabel 2, pada panjang gelombang hijau (510-580 $\mathrm{nm})$ menunjukkan bahwa lima jenis lamun membentuk dua kelompok baru (Gambar 5.1). Kelompok pertama terdiri dari lamun jenis Cymodocea rotundata dengan Cymodocea serrulata, Enhalus acoroides, dan Halophila ovalis. Kelompok selanjutnya hanya terdiri dari satu jenis lamun yaitu Thalassia hemprichii. Dapat disimpulkan bahwa Thalassia hemprichii memiliki karakteristik spektral yang sensitif terhadap panjang gelombang hijau.

Panjang gelombang kuning (585-625 $\mathrm{nm})$ memiliki karakteristik sensitif terhadap vegetasi dan dapat mendeteksi klorofil dari vegetasi tersebut. Analisis pengelompokkan pada panjang gelombang kuning (Gambar 5.2) membentuk dua kelompok utama yaitu jenis Cymodocea serrulata, Thalassia hemprichii, dan Enhalus acoroides. Kelompok kedua yang terbentuk adalah Cymodocea rotundata dan Halophila ovalis.
Berdasarkan kelompok yang terbentuk dari analisis klaster diketahui bahwa jenis Cymodocea rotundata dan Halophila ovalis tidak berbeda signifikan atau memiliki kemiripan, jenis Cymodocea serrulata dan Thalassia hemprichii memiliki perbedaan tetapi tidak signifikan, dan jenis yang paling berbeda signifikan dengan jenis lainnya adalah Enhalus acoroides. Disimpulkan bahwa karakteristik spektral lamun jenis Enhalus acoroides sensitif terhadap panjang gelombang kuning.

Identifikasi dari kesehatan sebuah vegetasi dapat dilakukan oleh panjang gelombang red edge atau merah tepi (705$745 \mathrm{~nm}$ ), dengan melihat produksi klorofil dari tanaman tersebut. Penelitian yang telah dilakukan tidak melakukan perhitungan klorofil. Hasil pengelompokan pada analisis panjang gelombang merah tepi adalah membentuk dua kelompok (Gambar 5.3). Kelompok pertama terdiri dari Cymodocea serrulata, Cymodocea rotundata, dan Enhalus acoroides. Ketiga jenis tersebut memiliki kemiripan spektral dengan jenis Enhalus acoroides, Cymodocea serrulata, dan Cymodocea rotundata. Kelompok selanjutnya adalah Thalassia hemprichii, yang memiliki nilai spektral reflektansi berbeda dengan keempat jenis lainnya.

Sama halnya dengan panjang gelombang hijau, NIR-2 (860-900nm) memiliki karakteristik panjang gelombang yang sensitif terhadap vegetasi terutama vegetasi laut (Gao 1996). Proses pengelompokan nilai reflektansi jenis lamun pada panjang gelombang NIR2 menghasilkan dua kelompok (Gambar 5.4). Kelompok pertama terdiri dari jenis Cymodocea serrulata dan Thalassia hemprichii yang memiliki kemiripan sangat tinggi, selanjutnya kelompok kedua yaitu antara jenis Cymodocea rotundata dan Halophila ovalis. Selanjutnya terdapat jenis Enhalus acoroides yang memiliki kemiripan 95\% dengan kelompok kedua dan memiliki kemiripan $82.16 \%$ dengan kelompok pertama. Dapat disimpulkan bahwa Enhalus acoroides memiliki perbedaan yang signifikan terhadap keempat jenis lainnya pada analisis panjang gelombang NIR-2. 


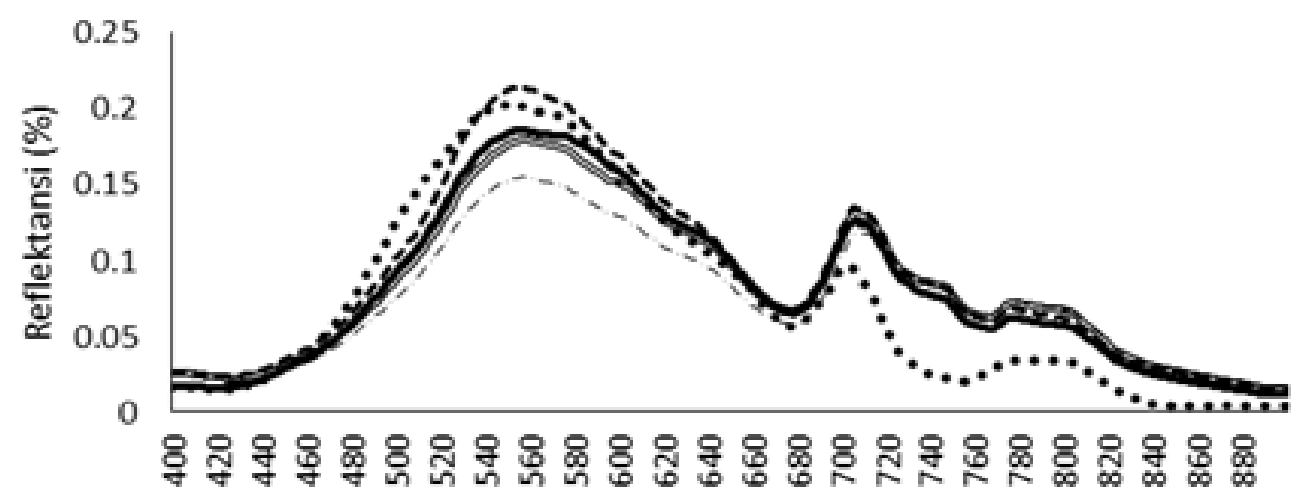

Gambar 3. Pola reflektansi lima jenis lamun

Cymodocea serrulata

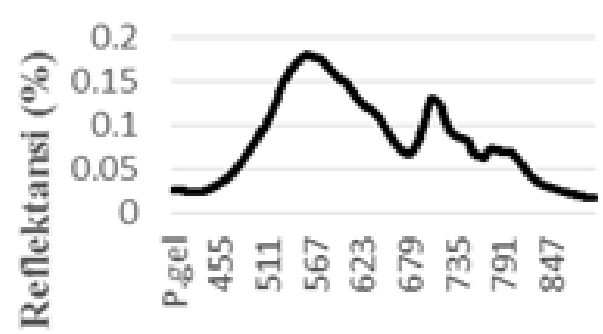

Panjang Gelombang (nm)

Panjang gelombang $(\mathrm{nm})$

Cymodocea serrulata

-----Enhalus acoroides

Cymodocea rotundata

...... Thalassia hemprichii 


\section{Halophila ovalis}

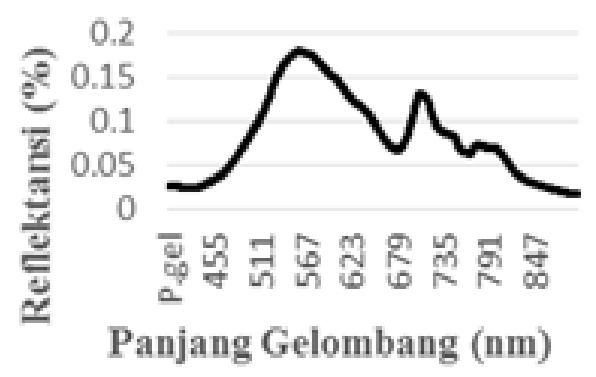

Gambar 4. Pola reflektansi spektral pada masing-masing jenis lamun

Tabel 1. Hasil uji ANOVA nilai reflektansi terhadap gelombang

\begin{tabular}{cccccc}
\hline Source of Variation & SS & $\boldsymbol{d f}$ & $\boldsymbol{F}$ & P-value & $\boldsymbol{F}$ crit \\
\hline Between Groups & 830.532 & 4 & 7.008666 & $1.31 \mathrm{E}-05$ & 2.375487 \\
Within Groups & 74062.95 & 2500 & & & \\
Total & 74893.49 & 2504 & & & \\
\hline
\end{tabular}
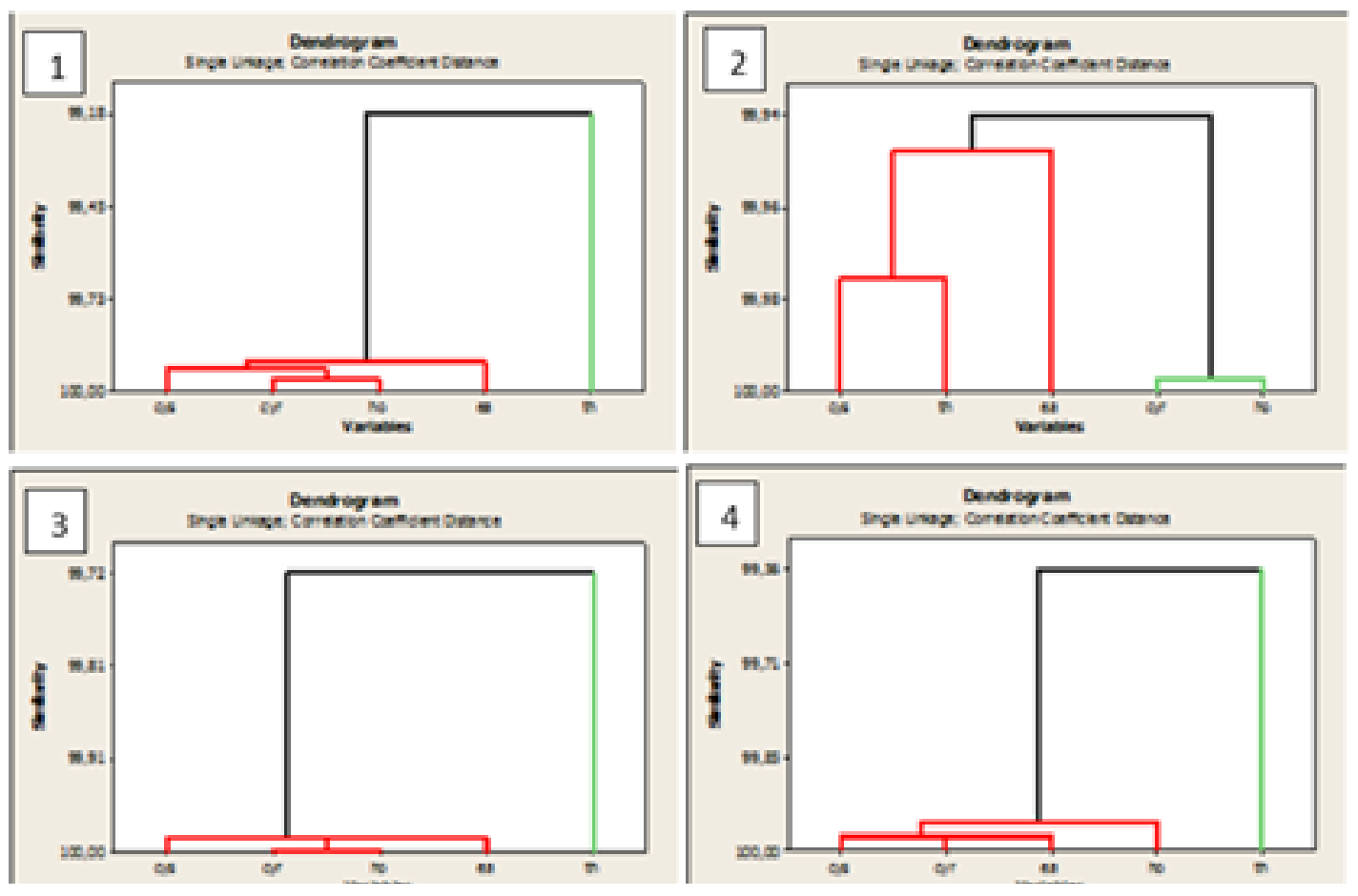

Gambar 5. Pengelompokan nilai reflektansi lamun panjang gelombang penciri pada (1) band hijau, (2) band kuning, (3) band merah tepi, dan (4) band NIR-2 
Tabel 2. Hasil uji Tukey

\begin{tabular}{clll}
\hline & \multicolumn{1}{c}{ Jenis } & Signifikan Alpha (0.5) \\
\hline Tukey HSD & Cymodocea rotundata & Cymodocea serrulata & 0.996 \\
& & Enhalus acoroides & 0.092 \\
& Thalassia hemprichii & 0.290 \\
& Halophila ovalis & 0.258 \\
\cline { 2 - 3 } & Cymodocea serrulata & Cymodocea rotundata & 0.996 \\
& Enhalus acoroides & 0.209 \\
& Thalassia hemprichii & 0.137 \\
& Halophila ovalis & 0.119 \\
\cline { 2 - 3 } Enhalus acoroides & Cymodocea rotundata & 0.092 \\
& Cymodocea serrulata & 0.209 \\
& Thalassia hemprichii & $0.000^{*}$ \\
& Halophila ovalis & $0.000^{*}$ \\
\hline Thalassia hemprichii & Cymodocea rotundata & 0.290 \\
& Cymodocea serrulata & 0.137 \\
& Enhalus acoroides & $0.000^{*}$ \\
& Halophila ovalis & 1.000 \\
\hline & Cymodocea rotundata & 0.258 \\
& Cymodocea serrulata & 0.119 \\
& Enhalus acoroides & $0.000^{*}$ \\
& Halophila ovalis & Thalassia hemprichii & 1.000 \\
\hline
\end{tabular}

*berbeda signifikan antar spesies

\section{KESIMPULAN DAN SARAN}

\section{Kesimpulan}

Kesimpulan yang diperoleh dari penelitian ini adalah reflektansi lamun memiliki dua peak (puncak) di panjang gelombang 500-650 $\mathrm{nm}$ (band hijau) dan 700-750 nm (merah tepi) dengan nilai tertinggi $22 \%$ di puncak pertama dan $14 \%$ di puncak kedua. Berdasarkan nilai reflektansi dari lima jenis lamun dan uji Tukey yang telah dilakukan, dapat diketahui panjang gelombang penciri karena lima jenis lamun memiliki perbedaan signifikan yaitu dipanjang gelombang hijau, kuning, merah tepi, dan NIR-2. Pengujian statistik untuk mengetahui karakteristik spektral lamun cukup dilakukan dengan analisis ragam yang dilanjutkan dengan uji Tukey dan analisis pengelompokkan (cluster analysis) berdasarkan kemiripan nilai spektral.

\section{Saran}

Disarankan untuk penelitian lanjutan dalam pengolahan data reflektansi spektral perlu dilakukan klasifikasi lamun hingga tingkat spesies menggunakan citra satelit. Perlu dilakukan kajian lebih lebih lanjut mengenai pengaruh kandungan lamun secara biologis terkait dengan reflektansi spektral. Diharapkan penelitian ini dapat memberikan informasi mengenai kurva spektral lamun secara in situ di Pulau Tunda dan dapat menjadi rujukan referesi bagi penelitian selanjutnya maupun perkembangan ilmu pengetahu-an dan teknologi.

\section{DAFTAR PUSTAKA}

Azkab MH. 2000. Struktur dan fungsi pada komunitas lamun. Oseana. 25(3):917.

Durako MJ. 2007. Leaf optical properties and photosynthetic leaf absorptances in several Australian seagrasses. Aquatic Botany. 87(1):83-89

Digitalglobe. 2010. Radiometric use of worldview-2 imagery: Technical note. 1601 Dry Creek Drive Suite 260 
Longmont USA: Colorado

Fyfe SK. 2003. Spatial and temporal variation in spectral reflectance: Are seagrass species spectrally distinct?. Limnol Oceanogr. 48:464-479.

Green EP, Mumby PJ, Edwards AJ, Clark. 2000. Remote Sensing Handbook For Tropical Coastal Management. Coastal Management Sourcebook 3. Paris: UNESCO.

Hochberg EJ, Atkinson MJ, Fouet SA. 2003. Spectral reflectance of coralreef bottomtypes worldwide and implications for coral reef remote sensing. Remote Sensing of Environment. (85):159-173

Indarto. 2014. Teori dan Praktek Penginderaan Jauh. Yogyakarta: Andi Offset

Lillesand TM, Kiefer RW, Chipman JW. 2004. Remote Sensing and Image Interpretation. United States of America: Jhon Wiley \& Sons.

McKenzie LJ, Campbell SJ, Roder CA. 2001. Seagrass-watch: manual for mapping and monitoring seagrass resourcess. Community (citizen) volunteers.

Mattjik AA, Sumertajaya IM. 2011. Sidik Perubahan Ganda dengan Menggunakan SAS. Departemen Statistika: Institut Pertanian Bogor

Mobley CD. 1994. Light and Water Radiative Transfer in Natural Water. California: Academic Press.

Ocean Optic. 2009. Spectra suite spectrometer operating software. USA: Ocean Optics, Inc. World Headquarters.

Pu R, Bell S, Baggett L, Mayer C, Zhao Y. 2012. Discrimination of seagrass species and cover classes with insitu hyperspectral data. Journal of Coastal Research. 6 (28): 1330-1344

Thorhaug A, Andrew DR, Grame P. 2006. Spectral reflectance of thalassia testidinum (hydrocharitaceae) seagrass: low salinity effect. American. Journal of Botany. 93(1):110-117. 